\title{
Mineral Fertilization Influences the Acceptability of Fresh Pulp and Juice Made from Sugarloaf Pineapple
}

\author{
Sabaï Kate ${ }^{*}$, Elvire Line Sossa ${ }^{2}$, Codjo Emile Agbangba ${ }^{3,4}$, Rodrigue Idohou ${ }^{3,5}$, \\ Edmond Sacla Aïde ${ }^{3}$, Gbènoukpo Pierre Tovihoudji ${ }^{6}$, Brice Sinsin ${ }^{7}$ \\ ${ }^{1}$ Institut National des Recherches Agricoles du Benin, Cotonou, Benin \\ ${ }^{2}$ Laboratoire des Sciences du Sol, Département de Production Végétale, Université d'Abomey-Calavi, Cotonou, Benin \\ ${ }^{3}$ Laboratoire de Biomathématiques et d'Estimations Forestières, Université d'Abomey-Calavi, Cotonou, Bénin \\ ${ }^{4}$ Laboratoire de Recherche en Biologie Appliquée, Ecole Polytechnique d'Abomey-Calavi, Université d'Abomey-Calavi, Cotonou \\ Benin \\ ${ }^{5}$ Ecole de Gestion et de Production Végétale et Semencière, Université Nationale d'Agriculture, Ketou, Benin \\ ${ }^{6}$ Laboratory of Hydraulics and Environmental Modeling (HydroModE-Lab), Faculté d'Agronomie, Université de Parakou, \\ Parakou, Benin \\ ${ }^{7}$ Laboratoire d'Ecologie Appliquée, Université d'Abomey-Calavi, Cotonou, Bénin \\ Email: *katesabai38@gmail.com
}

How to cite this paper: Kate, S., Sossa, E.L., Agbangba, C.E., Idohou, R., Sacla Aïde, E., Tovihoudji, G.P. and Sinsin, B. (2020) Mineral Fertilization Influences the Acceptability of Fresh Pulp and Juice Made from Sugarloaf Pineapple. Agricultural Sciences, 11, 342-353. https://doi.org/10.4236/as.2020.113020

Received: January 9, 2020

Accepted: March 17, 2020

Published: March 20, 2020

Copyright $\odot 2020$ by author(s) and Scientific Research Publishing Inc. This work is licensed under the Creative Commons Attribution International License (CC BY 4.0).

http://creativecommons.org/licenses/by/4.0/ (c) (i) Open Access

\begin{abstract}
Fertilization practices can influence the quality of pineapple fruit and consequently its acceptability by consumers who are increasingly oriented towards high quality agri-food products. This study aimed at evaluating the influence of N, P and $\mathrm{K}$ on some physico-chemical and organoleptic characteristics of pineapple (Ananas comosus L. Merr) for fresh consumption and juice processing. A complete NPK factorial design was installed in the south Benin. The treatments NPK in g plant-1 were randomized into four blocks: T1; T2; T3; T4; T5; T6; T7; T8; T9. Brix juice was determined using a refractometer and $\mathrm{pH}$ with a $\mathrm{pH}$ meter. An evaluation of sensory characteristics such as sweetness, acid taste and aroma of fresh pineapple pulp and processed juice was made by a panel of tasters selected and trained. A principal components analysis, followed by a numerical classification was performed on fruits' sensory and physicochemical characteristics. Results showed that juice $\mathrm{pH}$ was significantly influenced by the phosphorus and potassium. Potassium influenced significantly juice yield. Some physico-chemical characteristics and sensory attributes were correlated between them and groups of treatments are formed for both the juice and the fresh fruit.
\end{abstract}

\section{Keywords}

Ananas comosus, Fertilizer, Fruit, Intensification, Juice, Sensory 


\section{Introduction}

Pineapple (Ananas comosus L. Merr) is the second tropical fruit in world trade, and contributes to more than $20 \%$ with a production of 17 million tonnes [1]. In West Africa, Benin is the second major producer, with 160.000 tonnes in 2011 after Nigeria [2]. The edible part of pineapple fruit (60\% of the fresh fruit) is made up of $85 \%$ water, $0.4 \%$ protein, $14 \%$ sugar, $0.1 \%$ fat and $0.5 \%$ fibre [3]. Moreover, pineapple fruit is a good source of vitamins A, B1, B6 and C, copper, manganese and dietary fibre [4] [5]. The consumption of pineapple contributes to food and nutritional balance of populations. Analysis of the pineapple supply chain showed that the major constraints encountered by producers, wholesalers and processors are the heterogeneity in pineapple quality produced or delivered, poor compliance with quality criteria such as size and sugar concentration, and late delivery [6]. Heterogeneity in pineapple fruit quality (fruit weight and length attributes) at harvest was associated with heterogeneity in plant vigour at flowering induction time [7]. However, the cultural practices, those that guarantee a plant vigour achieving uniform plant development before flower induction need to receive considerable attention.

A nutrient imbalance in soil has been already diagnosed in Benin pineapple production areas [8] [9] [10]. These authors hypothesized that this soil nutrient imbalance should limit not only yield but also fruit quality. The optimal combination of fertilizers (N, P and $\mathrm{K}$ ) for Smooth cayenne juice oriented production has been carried out [11]. Most works on pineapple fertilization only specify the type or quantity of fertilizer for quality fruit production [11] [12] [13] [14] without linking fertilization to the goal of production. However, juice yield and juice quality are the main factors that interest juice producers. In other words, farmers would prefer fertilizers that ensure quality and quantity of juice if their goal was to supply pineapple for juice processing factory. To date, there is no study carried out on a variety of sugarloaf cultivation in Benin, despite its importance. Since the biggest fresh pineapple outlets are the national fresh pineapple markets $(35 \%)$ and regional markets $(40 \%)$ in Nigeria, Niger, Burkina-Faso and Togo [15], cultural practices meeting local standard remain important.

In this paper we hypothesize that mineral fertilizer $\mathrm{N}, \mathrm{P}$ and $\mathrm{K}$ would improve fruit quality and determine fruit acceptability for fresh consumption or for juice processing. The objective of the study was thus to evaluate the influence of fertilizer $\mathrm{N}, \mathrm{P}$ and $\mathrm{K}$ on physico-chemical and organoleptic characteristics on pineapple for fresh consumption and juice processing in Benin.

\section{Materials and Methods}

\subsection{Experimental Site}

This study was conducted in the Atlantic department in the south of Benin between April 13, 2013 and June 23, 2014. This is located at 6 ${ }^{\circ} 40^{\prime} 0^{\prime \prime} \mathrm{N}$ and $2^{\circ} 15^{\prime} 0^{\prime \prime} \mathrm{E}$. The nitrogen content was $0.08 \%$ with a weakly acid $\mathrm{pH}(6.5)$. The carbon/nitrogen ratio was 10.3 . The organic matter content is low (1.38\%). Soil ex- 
changeable potassium content is low $\left(0.03 \mathrm{cmol} \cdot \mathrm{kg}^{-1}\right)$; while content of available phosphorus in soils by Bray 1 was also low $\left(5 \mathrm{mg} \cdot \mathrm{kg}^{-1}\right)$. The soil was poor in exchangeable $\mathrm{Ca}$ and $\mathrm{Mg}$ (1.8 to $2.8 \mathrm{cmol} \cdot \mathrm{kg}^{-1}$ ). The sum of bases and CEC are low $\left(4.8\right.$ to $\left.5.4 \mathrm{cmol} \cdot \mathrm{kg}^{-1}\right)$.

\subsection{Experiment Design and Treatments}

The experimental design was a full factorial design; generated with Minitab16 software. The minimum and maximum levels for each factor were $\mathrm{N}$ (2.7 and 10.7 g.plant $\left.{ }^{-1}\right) ; \mathrm{P}\left(0.5\right.$ and 2.7 g.plant $\left.{ }^{-1}\right)$ and $\mathrm{K}\left(2.7\right.$ and $16 \mathrm{~g} \cdot$ plant $\left.^{-1}\right)$. The minima and maxima were fixed taking into account the minimum rates that producers apply [16] [17] and the maximum rates that the producer may not exceed [5]. In the case of $2^{\mathrm{k}}$ factorial trials, the addition of further observations located in the center of factorial design also provides the opportunity to check the possible linearity relationship between the observed and the variable factors [18]. So, the T1 treatment $\left(6.7-1.6-9.3\right.$ plant $\left.^{-1}\right)$ was introduced as a central point and repeated twice per block. Other treatments (summit points) were repeated twice on the whole design. This allowed to generate 9 treatments: T1: $6.7-1.6-9.3$ g.plant ${ }^{-1}$; T2: $2.7-2.7-2.7$ g.plant ${ }^{-1}$; T3: $10.7-0.5-2.7$ g.plant ${ }^{-1}$; T4: $10.7-2.7$ -16 g.plant ${ }^{-1}$; T5: $2.7-0.5-16$ g.plant ${ }^{-1}$; T6: $2.7-2.7-16$ g.plant ${ }^{-1}$; T7: $10.7-2.7$ - 2.7 g.plant ${ }^{-1}$; T8: 2.7 - 0.5 - 2.7 g.plant ${ }^{-1}$ and T9: 10.7 - 0.5 - 16 g.plant ${ }^{-1}$. Four blocks each of six experimental units were, thus formed, which allowed to have 24 experimental units. Each experimental unit consisted of 6 lines of 5 plants. The line spacing was $0.8 \mathrm{~m}$ and $0.4 \mathrm{~m}$ between planting holes, making a density of 60,000 plant $\cdot \mathrm{ha}^{-1}$. Planting material weighing between 400 and $500 \mathrm{~g} \cdot \mathrm{plant}^{-1}$ were used. The uniform size of material was used in each block.

The mineral fertilizers used were: urea $(46 \% \mathrm{~N})$, triple superphosphate $(46 \%$ $\left.\mathrm{P}_{2} \mathrm{O}_{5}\right)$ and potassium sulfate $\left(\mathrm{K}_{2} \mathrm{SO}_{4}, 50 \% \mathrm{~K}_{2} \mathrm{O}, 45 \% \mathrm{SO}_{3}\right)$. The first fertilizer application was done a week after planting $\left(\mathrm{P}_{2} \mathrm{O}_{5}\right)$, the second 45 days after planting (DAP) $\left(1 / 5 \mathrm{~N}+1 / 6 \mathrm{~K}_{2} \mathrm{O}\right)$, the $3 \mathrm{rd} 90 \mathrm{DAP}\left(1 / 5 \mathrm{~N}+1 / 6 \mathrm{~K}_{2} \mathrm{O}\right)$, the 4 th $135 \mathrm{DAP}$ $\left(1 / 5 \mathrm{~N}+1 / 6 \mathrm{~K}_{2} \mathrm{O}\right)$, the 5 th $180 \mathrm{DAP}\left(1 / 5 \mathrm{~N}+1 / 6 \mathrm{~K}_{2} \mathrm{O}\right)$, the $6^{\text {th }} 225 \mathrm{DAP}(1 / 5 \mathrm{~N}+$ $\left.1 / 6 \mathrm{~K}_{2} \mathrm{O}\right)$ and the $7^{\text {th }} 270 \mathrm{DAP}\left(1 / 6 \mathrm{~K}_{2} \mathrm{O}\right)$.

Flowering induction was carried out ten months after planting using carbide of calcium $\left(\mathrm{CaC}_{2}\right)$, a compound producing acetylene when reacted with water. A kilogram of product was diluted in a barrel of 200 liters. Each plant received 50 $\mathrm{cm}^{3}$ of acetylene carbide and the application was done between $6-8 \mathrm{am}$.

\subsection{Physico-Chemical Characteristics Measurement and Juice Processing}

Six fruits per experimental unit were harvested at maturity (fully colored fruit). Each fruit was peeled using a knife and crushed using a crusher. The pulp was pressed using a press stainless steel; filtered to extract fresh juice and juice yield determined using a brand DH2-000050 balance, \pm 0.0001 . Brix (total sugars) juice was determined by a refractometer, HI96801, and $\mathrm{pH}$ using the $\mathrm{pH}$ meter 
HI96107, $\pm 0.1 \mathrm{pH}$. Juice was prepared following the current procedures in the pineapple juice processing unit "Original Pineapple Juice" of the Regional Association of Pineapple Producers of Atlantic [11]. All of the materials and machine used on stainless.

\subsection{Sensory Analysis}

The evaluation of the organoleptic characteristics of the fresh pineapple and processed juice was made according to [19].

\subsubsection{Panel of Expert Tasters}

Initially, a group of 30 students in agronomy from the Catholic University of West Africa (UCAO) was chosen and filtered based on their sensory acuity on basic tastes. Firstly, they were asked to identify the acidity, sweetness and bitterness respectively in samples of lemon solutions, sugar and coffee. This was by asking them to identify the basic tastes and smells of the basic flavors with defined concentrations that were the sweet solution prepared with $10 \mathrm{~g} \cdot \mathrm{kg}^{-1}$ of sugar; salted with sodium chloride $2 \mathrm{~g} \mathrm{~kg}^{-1}$; acid with citric acid $0.4 \mathrm{~g} \cdot \mathrm{kg}^{-1}$; bitter with caffeine $0.5 \mathrm{~g} \cdot \mathrm{kg}^{-1}$. The sensitivity of tasters was tested in a second time by subjecting them to a triangular test, which was to identify the different pineapple samples for the three samples that were presented (Two being known identical and one different). At the end of this stage, 20 people were selected as having the most pronounced taste and were more sensitive to flavors intensity variations.

After this first selection, the 20 panelists were subjected to an intensity rating test to determine their sensitivity to different characteristics of the juice and pineapple fruit pulp. Three pineapple samples (pulp and juice), with known physico-chemical characteristics, and different, were used for this purpose. A group of 13 people who had demonstrated superior performance in these tests was selected for training on intensity rating test on pineapple samples from mineral nutrition tests. During this stage, the procedures that suited best to the preparation and presentation of the samples were developed, as well as completing the bulletins.

\subsubsection{Sensory Test}

On each product (pineapple pulp and processed juice), two sections of tasting test were carried out on the same day, one in the morning and the second in the evening. Two representative fruits were harvested by experimental unit and sensory characteristics assessed by the panel of tasters selected and trained enough. Juice samples produced were collected in coded cups at a rate of $15 \mathrm{ml}$ per cup. As for the fresh pulp, each fruit was disgusted, peeled and cut into slices. A total of ten samples from tested treatments in comparison with a sample from farmer production (T0) were tested. Pineapple pieces of the same experimental unit were well mixed and three randomly selected pieces were arranged in white plastic plates coded with random 3-digit numbers. Each sample had a separate number. All samples were presented simultaneously to each taster in 
random order. Each taster could eat as several samples; while rinsing the mouth with deionized water before moving to another sample. The sensory characteristics assessed were the sweetness, acid taste and aroma of fruit pulp and processed juice with an intensity rating test using a scale of 5 categories at levels ranging from "No (acid, sweet, aroma)" to extremely (acid, sweet, aroma). Both types of samples (pulp and juice) were evaluated on two different days.

\subsection{Statistical Analysis}

Analysis of variance, followed by least significant difference (LSD) test, was used to compare means using package "agricolae" in $\mathrm{R}$ software (version R.3.1.0, 2014). Then, a principal components analysis, followed by a hierarchical classification on the coordinates of the principal components, was performed with the package "FactoMineR" on sensory attributes and physico-chemical parameters. To select the sensory attributes and physico-chemical parameters of each class, we measure the difference between the values for class and overall values. These statistics can be converted into a criterion called value-test to make a selection on the variables, and thus designate the most characteristic variables [20] [21]. The most characteristic variables of a class were those whose associated values test were greater in absolute value than 2. Moreover, if this value test was positive for a variable, it had a high value in the class under consideration. In contrast, if the value was negative, the variable had a low value for the class.

\section{Results}

\subsection{Physico-Chemical Quality of Pineapple Juice}

Nitrogen had no significant effect on total sugar, $\mathrm{pH}$ and juice yield (Table 1). However, $\mathrm{P}_{2} \mathrm{O}_{5}$ significantly affected $(\mathrm{Prob}=0.01) \mathrm{pH}$, which had the lowest value with the rate $1.6 \mathrm{~g} \mathrm{P}_{2} \mathrm{O}_{5}$ per plant, but this element had no effect on Brix and juice yield. Potassium significantly affected the $\mathrm{pH}$, which decreased with rate, and juice yield increased with rate; but this element had no effect on the Brix (Table 1). Treatment T8 (2.7 - $0.5-2.7$ g.plant $\left.{ }^{-1}\right)$ showed the highest levels of total sugars, followed respectively by treatments T9 (10.7 - $0.5-16$ g.plant $\left.{ }^{-1}\right)$, T5 (2.7 - 0.5 - 16 g.plant $\left.{ }^{-1}\right)$, T6 (2.7 $2.7-16$ g.plant $\left.{ }^{-1}\right)$, T1 (6.7 - $1.6-9.3$ g.plant $\left.{ }^{-1}\right)$, T7 (10.7 - $2.7-2.7$ g.plant $\left.{ }^{-1}\right)$ and T4 $\left(10.7-2.7-16\right.$ g.plant $\left.^{-1}\right)$; while the lowest concentrations were observed with treatment T2 $(2.7-2.7-2.7$ g.plant $\left.{ }^{-1}\right)$ and T3 $\left(10.7-0.5-2.7\right.$ g.plant $\left.{ }^{-1}\right)$. Treatment T3 showed the highest $\mathrm{pH}$; while other treatments were similar among themselves. The highest juice yield was achieved with T9, T8 and then T6, followed by treatments T1, T4 and T5. The lowest values were obtained with treatments T3, T7 and T2 (Table 1).

\subsection{Physico-Chemical and Organoleptic Quality of the Fresh Pineapple Pulp}

Results of the principal component analysis revealed that the first two components explained $73.95 \%$ of the total variance (Figure 1$)$. Sweetness $(r=0.94$, 
Table 1. Effect of N, P and $\mathrm{K}$ on total sugar, $\mathrm{pH}$ and juice yield.

\begin{tabular}{|c|c|c|c|}
\hline Fertilizer & Total sugar & $\mathrm{pH}$ & Juice yield \\
\hline g.plant ${ }^{-1}$ & ${ }^{\circ}$ Brix & & l.plant ${ }^{-1}$ \\
\hline \multicolumn{4}{|l|}{ Nitrogen } \\
\hline 2.7 & $15.24 \mathrm{a}$ & $5.55 \mathrm{a}$ & $0.90 \mathrm{a}$ \\
\hline 6.7 & $15.15 \mathrm{a}$ & $5.42 \mathrm{a}$ & $0.91 \mathrm{a}$ \\
\hline 10.7 & $14.75 \mathrm{a}$ & $5.55 \mathrm{a}$ & $0.88 \mathrm{a}$ \\
\hline \multicolumn{4}{|l|}{ Phosphorus } \\
\hline 0.5 & $15.33 \mathrm{a}$ & $5.58 \mathrm{a}$ & $0.94 \mathrm{a}$ \\
\hline 1.6 & $15.19 \mathrm{a}$ & $5.42 \mathrm{~b}$ & $0.91 \mathrm{a}$ \\
\hline 2.7 & $14.62 \mathrm{a}$ & $5.52 \mathrm{ab}$ & $0.84 \mathrm{a}$ \\
\hline \multicolumn{4}{|l|}{ Potassium } \\
\hline 2.7 & $14.70 \mathrm{a}$ & $5.60 \mathrm{a}$ & $0.81 \mathrm{~b}$ \\
\hline 9.3 & $15.18 \mathrm{a}$ & $5.42 \mathrm{~b}$ & $0.91 \mathrm{ab}$ \\
\hline 16 & $15.26 \mathrm{a}$ & $5.50 \mathrm{ab}$ & $0.97 \mathrm{a}$ \\
\hline \multicolumn{4}{|c|}{ Nitrogen ${ }^{\star}$ Phosphorus ${ }^{\star}$ Potassium } \\
\hline $\mathrm{T}_{1}: 6.7-1.6-9.3$ & $15.15 \mathrm{abc}$ & $5.42 \mathrm{ab}$ & $0.92 \mathrm{abc}$ \\
\hline $\mathrm{T}_{2}: 2.7-2.7-2.7$ & $14.23 \mathrm{bc}$ & $5.60 \mathrm{ab}$ & $0.64 \mathrm{~d}$ \\
\hline $\mathrm{T}_{3}: 10.7-0.5-2.7$ & $14.02 \mathrm{c}$ & $5.72 \mathrm{a}$ & $0.78 \mathrm{~cd}$ \\
\hline $\mathrm{T}_{4}: 10.7-2.7-16$ & $14.49 \mathrm{abc}$ & $5.57 \mathrm{ab}$ & $0.86 \mathrm{abcd}$ \\
\hline $\mathrm{T}_{5}: 2.7-0.5-16$ & $15.63 \mathrm{ab}$ & $5.45 \mathrm{ab}$ & $0.82 \mathrm{bcd}$ \\
\hline $\mathrm{T}_{6}: 2.7-2.7-16$ & $15.22 \mathrm{abc}$ & $5.50 \mathrm{ab}$ & $1.08 \mathrm{a}$ \\
\hline $\mathrm{T}_{7}: 10.7-2.7-2.7$ & $14.60 \mathrm{abc}$ & $5.43 \mathrm{ab}$ & $0.78 \mathrm{~cd}$ \\
\hline $\mathrm{T}_{8}: 2.7-0.5-2.7$ & $15.89 a$ & $5.67 \mathrm{a}$ & $1.05 \mathrm{ab}$ \\
\hline $\mathrm{T}_{9}: 10.7-0.5-16$ & $15.71 \mathrm{ab}$ & $5.50 \mathrm{ab}$ & $11.1 \mathrm{a}$ \\
\hline
\end{tabular}

Means that do not share a letter are significantly different at 5\% using Fisher's Least Significant Difference (LSD).

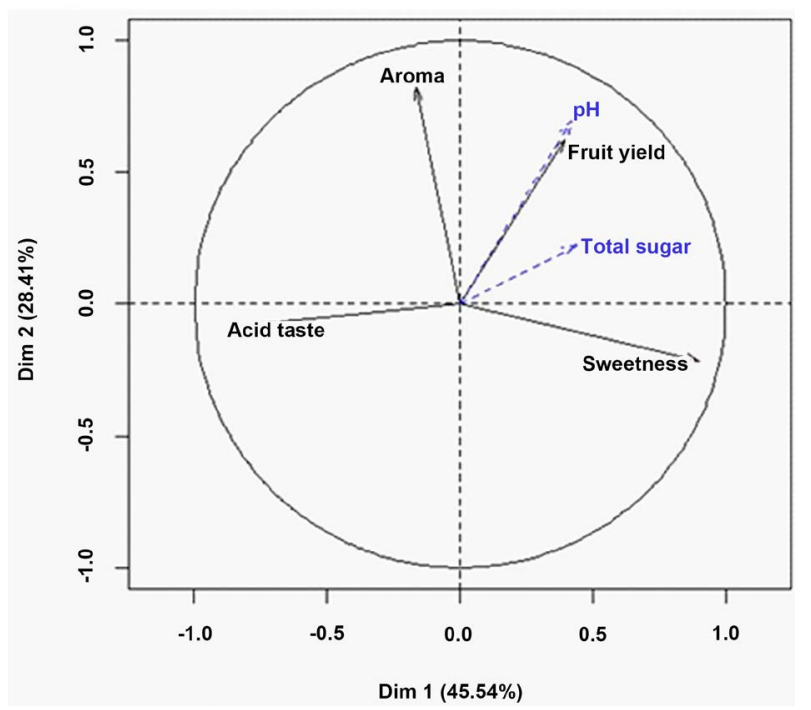

Figure 1. Correlation between physico-chemical and organoleptic characteristics of fresh pineapple pulp with the first two dimensions of the principal components analysis map. 
Prob $=0.000$ ) had a positive correlation and was very highly significant with the first dimension; while the acid taste was strongly and negatively correlated $(\mathrm{r}=$ -0.87 , Prob $=0.000)$ with this axis. Brix had a weak positive correlation with the first dimension $(r=0.44$, Prob $=0.05)$. The variables fruit yield $(r=0.63$, Prob $=$ $0.00)$, aroma $(r=0.83$, Prob $=0.00)$ and $\mathrm{pH}(\mathrm{r}=0.70$, Prob $=0.03)$ were positively and strongly correlated to the second dimension (Figure 1).

Based on the hierarchal classification, indicated that the treatments were grouped into 3 clusters (Figure 2) on the basis of physico-chemical characteristics, sensory and yield. The groups were: Cluster 1: T3, T4, T5 and T8; Cluster2: T0; Cluster 3: T1, T2, T6, T7 and T9.

The most variables discriminating clusters were: sweetness, acidic taste and fruit yield. Cluster 1 was characterized by sweetness of fruit (V. test $\geq 2$, Prob $<$ $0.05)$ and a very weak acid taste (V. test $\leq-2$, Prob $<0.05)$. Cluster 2 was defined by low weight of fruits and low $\mathrm{pH}$. Cluster 3 had a particularly weakly pronounced sweetness (Table 2). Treatments T3, T4, T5 and T8 were promising for a quality pineapple production for fresh consumption.

\subsection{Physico-Chemical and Organoleptic Quality of Pineapple Juice}

The first two axes explained $80.82 \%$ of the total inertia (Figure 3 ). The first component (axis 1) contained $59.96 \%$ of inertia and the second (axis 2) $20.86 \%$. The variables sweetness $(r=0.95$, Prob $=0.00)$, juice yield $(r=0.78$, Prob $=$ $0.00), \mathrm{pH}(\mathrm{r}=0.94$, Prob $=0.00)$ and Brix $(\mathrm{r}=0.81$, Prob $=0.01)$ were strongly

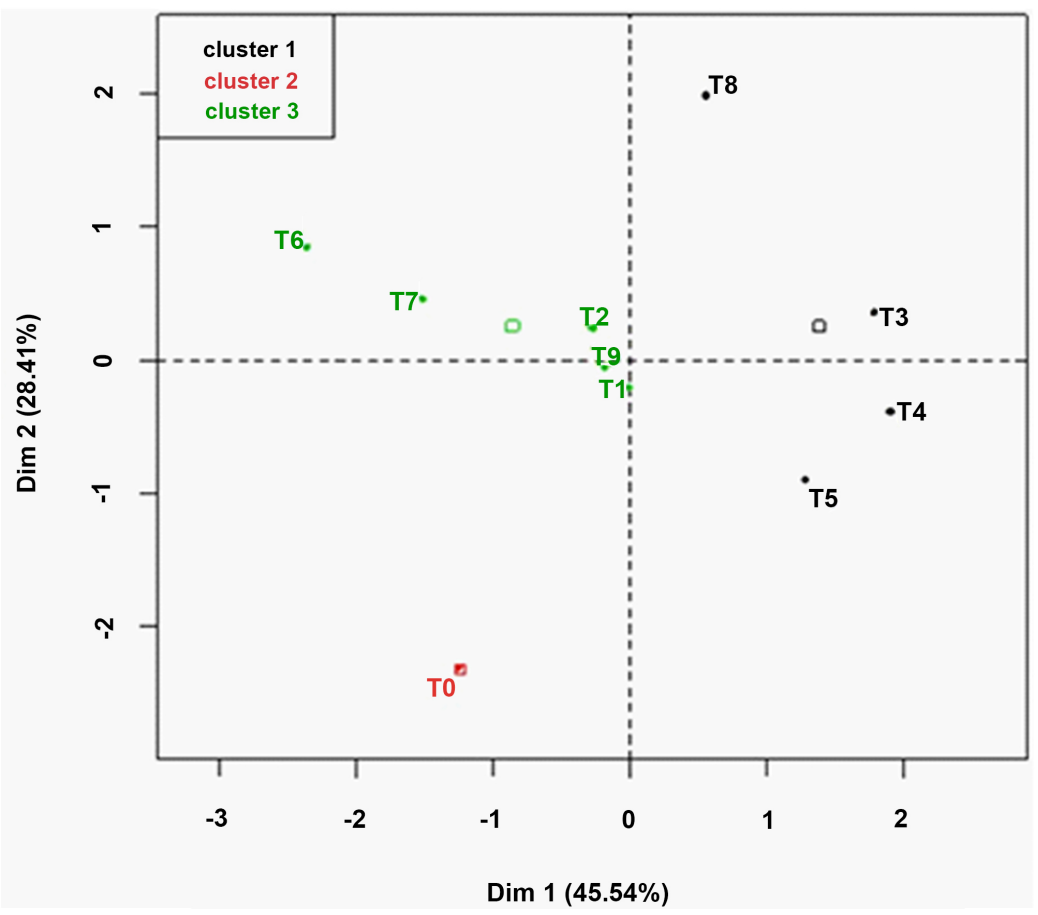

Figure 2. Projection of clusters of treatments according to physico-chemical and organoleptic parameters of fresh pineapple pulp in the principal components analysis map. 
Table 2. Discriminant variables of clusters of treatments for the physico-chemical and organoleptic characteristics of fresh pineapple pulp.

\begin{tabular}{ccccc}
\hline Parameters & Clusters & V. test & Mean & Probability \\
\hline Sweetness & 1 & 2.25 & 3.61 & 0.02 \\
Acidity & & -2.47 & 1.31 & 0.01 \\
Fruit yield & 2 & -2.58 & 1 & 0.00 \\
pH & & -2.93 & 4 & 0.00 \\
Sweetness & 3 & -2.23 & 2.75 & 0.03 \\
\hline
\end{tabular}

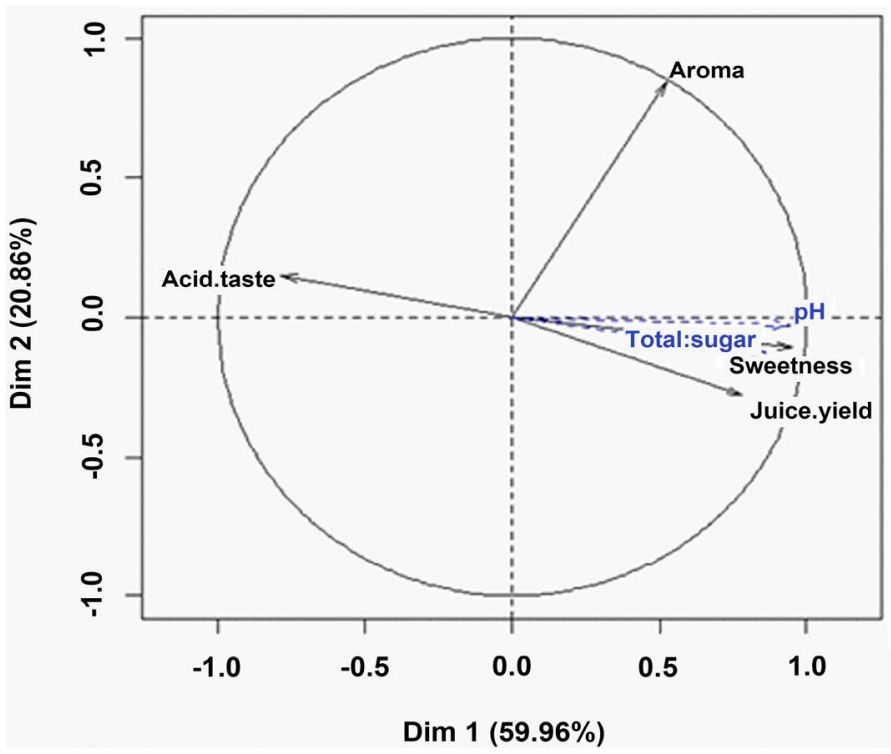

Figure 3. Correlation between physico-chemical and organoleptic characteristics of pineapple processed juice with the first two dimensions of the principal components analysis map.

and positively correlated with the first dimension; while the variable acid taste ( $\mathrm{r}$ $=-0.78$, Prob $=0.00$ ) was negatively correlated with it. Aroma was positively correlated with the component $2(r=0.84$, Prob $=0.00)$ (Figure 3 ).

The treatments were discriminated into four clusters (Figure 4). Cluster 1 (T0) was characterized by low yield of juice with an acid taste (V.test $\geq 2$, Prob $\leq$ 0.05 ), with a weak total sugar content, sweetness and $\mathrm{pH}$. A good flavored juice particularized T7 (cluster 2).

The class 3 was characterized by the treatments T2, T3 and T8 having weakly acidic pineapple juice (V.test $\leq-2$, Prob $\leq 0.05$ ). High juice yield (V.test $\geq 2$, Prob $\leq 0.05)$ distinguished Cluster 4 (T1, T4, T5, T6 and T9) (Table 3). It appeared that the treatments $\mathrm{T} 1, \mathrm{~T} 4, \mathrm{~T} 5, \mathrm{~T} 6$ and $\mathrm{T} 9$ had average organoleptic quality and allowed appreciable juice yield.

\section{Discussion}

The triple superphosphate and potassium fertilization influenced the physico-chemical characteristics and organoleptic of pineapple sugarloaf; and 


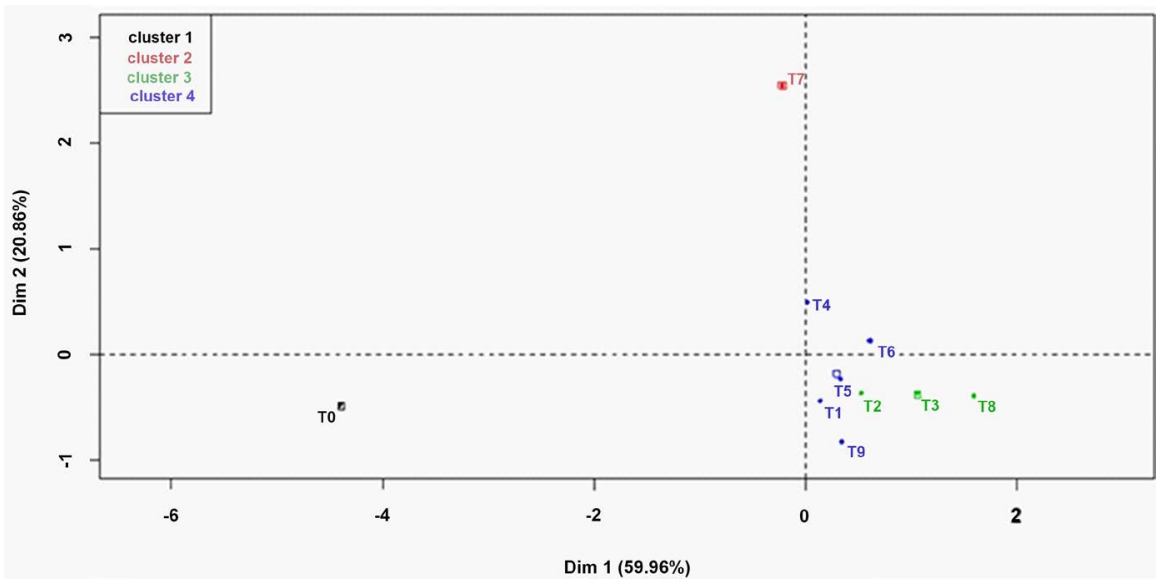

Figure 4. Projection of clusters of treatments according to physico-chemical and organoleptic parameters of pineapple processed juice in the principal components analysis map.

Table 3. Discriminant variables of clusters of treatments for the physico-chemical and organoleptic characteristics of pineapple processed juice.

\begin{tabular}{ccccc}
\hline Parameters & Clusters & V. test & Mean & Probability \\
\hline Acid taste & & 2.02 & 2.20 & 0.04 \\
Aroma & & -1.97 & 2.00 & 0.05 \\
Juice yield & 1 & -2.28 & 0.50 & 0.02 \\
Sweetness & & -2.56 & 3.00 & 0.01 \\
pH & & -2.58 & 5.00 & 0.01 \\
Total sugar & 2 & --2.62 & 12.00 & 0.01 \\
Aroma & 2.25 & 3.50 & 0.02 \\
Acid taste & 3 & -2.29 & 1.42 & 0.02 \\
Juice yield & 4 & 2.03 & 0.96 & 0.04 \\
\hline
\end{tabular}

determined the acceptability of fresh pulp and processed juice in Benin (Table 1). The positive influence of potassium fertilization on the size and fruit quality has been proven by several researchers [11] [12] [13] [14]. Increasing nitrogen rates may reduce the sugar content of fruits or have no significant effect on Brix [22] as is the case with the sugarloaf in this work. Potassium also significantly reduced $\mathrm{pH}$ and improved juice yield. The opposite trend was observed in Brazil on the variety Smooth Cayenne by [14]; where the potassium effect on $\mathrm{pH}$ was positive. Potassium has a significant effect on the quality of the fruit. In our trial, most of treatments selected as promising for pineapple production oriented for fresh pulp consumption or juice production contained relatively high rate of potassium (Table 1). An increase in potassium level in the plant results in: 1) improved fragrance and flavour of the fruit, 2) an increase in the diameter of the peduncle, so the resistance to lodging, but also a decrease in the performance of pulp, 3) poorer coloring of the pulp that remains white, 4) a good coloring of the skin and firm pulp [23]. 
Phosphorus influenced significantly the $\mathrm{pH}$ and an increase in the phosphorus tends to decrease the $\mathrm{pH}$. In contrast, many authors observed no response of phosphorus, despite the very low concentrations of the element in the soil [14]. Phosphorus response in this work should be explained by a characteristic deficiency of this element in lateritic soils in southern Benin. The promising rates of fertilizer $\mathrm{N}$ and $\mathrm{K}$ are within the standards recommended by [5]: 4 - $14 \mathrm{~g} \mathrm{~N}, 10$ to $20 \mathrm{~g} \mathrm{~K}$ per plant. The ratio $\mathrm{K} / \mathrm{N}$ for promising treatments ranged 0.25 and 5.93. This ratio may approach one for industrial production (pulp, juice) [24]. In this work, the methodology used to select appropriate treatments for high yielding and high quality includes sensory analysis. The quality of the pineapple fruit is defined by the set of characteristics that improves the taste [25]. The size, shape, and colour, characteristics of the pulp and sensory properties are the characteristics that determine the acceptability of the pineapple fruit on the market [26]. The methodology used in this study can therefore be used for all soil fertility management programs to take into consideration not only the improvement of yield but also to test the physico-chemical and sensory characteristics which are essential for a sustainable adoption of developed technologies. Furthermore, several studies have addressed the influence of mineral nutrition on fruit yield and juice quality, but very few studies have examined the influence of mineral nutrition on juice yield. However, juice yield and juice quality are the two major factors interesting juice producers. Reinhardt and Neiva (1986); Reference [27] showed an increase in the fruit juice content with increasing rates of nitrogen. Our results showed a rather positive influence of potassium on the juice yield.

\section{Conclusion}

There is a positive influence of fertilizer $\mathrm{P}$ and $\mathrm{K}$ on the quality of fresh pineapple pulp and pineapple juice (Ananas comosus L. Merr) produced in Benin. The treatments T4 (10.7 - 2.7 - 16 g.plant $^{-1}$ ) and T5 (2.7- 0.5 - 16 g.plant ${ }^{-1}$ ) are promising for fresh consumption or juice processing oriented pineapple production. The treatments T3 (10.7 - 0.5 - $2.7 \mathrm{~g}$.plant $\left.{ }^{-1}\right)$ and T8 (2.7 - $0.5-2.7$ g.plant $\left.{ }^{-1}\right)$ are specific for fresh consumption pineapple whereas T1 (6.7 - 1.6 - 9.3 g.plant $\left.^{-1}\right)$, T6 (2.7 - $2.71-16$ g.plant $\left.{ }^{-1}\right)$ and T9 (10.7 - $0.5-16$ g.plant $\left.{ }^{-1}\right)$ have an average organoleptic quality of juice and also allow having an appreciable juice yield. We conclude that fertilizers' recommendation to farmers for pineapple cultivation may respect the purpose of the production.

\section{Acknowledgements}

The authors are grateful to the pineapple producers and laboratory technicians who contributed to the realization of this work.

\section{Conflicts of Interest}

The authors declare no conflicts of interest regarding the publication of this paper. 


\section{References}

[1] FAO (2018) World Ranking: Pineapples, by Production (Tonnes).

[2] FAOSTAT (2018) Statistical Division of the UN Food and Agriculture Organization. http://www.fao.org/faostat/en/\#home

[3] Purseglove, J.W. (1972) Tropical Crops, Monocotyledons. Longman, London.

[4] Morton, J.F. (1987) Fruits of Warm Climates. Morton, J.F., Ed. Miami, Florida.

[5] Mateljan, G. (2007) The Worlds Healthiest Foods. Mateljan, G., Ed. Seattle, WA.

[6] Fassinou Hotegni, H.V.N., Lommen, W.J.M., Van der Vorst, J.G.A.J., Agbossou, E.K. and Struik, P.C. (2012) Analysis of Pineapple Production Systems in Benin. Acta Horticulturae, 928, 47-58. https://doi.org/10.17660/ActaHortic.2012.928.4

[7] Fassinou, H.V.N., Lommen, W.J.M., Agbossou, E.K. and Struik, P.C. (2014) Heterogeneity in Pineapple Fruit Quality within Crops Results from Plant Heterogeneity at Flower Induction. Frontier in Plant Science, 5, 670. https://doi.org/10.3389/fpls.2014.00670

[8] Agbangba, C.E., Dagbénonbakin, D.G. and Kindomihou, V. (2010) Etablissement des normes du Système Intégré de Diagnostic et de Recommandation de la culture d'ananas (Ananas comosus (L.) Merr) variété Pain de sucre en zone subéquatoriale du Bénin. Parakou, 1, 51-69.

[9] Dagbenonbakin, D.G., Agbangba, C.E. and Kindomihou (2010) Comparaison du système intégré de diagnostic et de recommandation et de la méthode de la valeur critique pour la détermination du statut nutritionnel de l'ananas (Ananas comosus (L.). Merr) variété Cayenne Lisse au Bénin. International Journal of Chemical and Biological Science, 4, 1550-1563. https://doi.org/10.4314/ijbcs.v4i5.65564

[10] Agbangba, C.E., Sossa, E.L., Dagbenonbakin, D.G., Diatta, S. and Akpo, L.E. (2011) DRIS Model Parameterization to Access Pineapple Variety "Smooth Cayenne" Nutrient Status in Benin (West Africa). Journal of Asian Scientific Research, 1, 254-264.

[11] Agbangba, C.E., Dagbenonbakin, G.D., Djogbénou, C.P., Houssou, P., Assea, D.E., Sossa, E.L., Kotomalè, U.A., Ahotonou, P., Ndiaga, C. and Akpo, L.E. (2015) Influence de la fertilisation minérale sur la qualité physico-chimique et organoleptique $\mathrm{du}$ jus d'ananas Cayenne lisse au Bénin. International Journal of Biological and Chemical Science, 9, 1277-1288. https://doi.org/10.4314/ijbcs.v9i3.13

[12] Teisson, C., Lacoeuilhe, J.J. and Combres, J.C. (1979) Le brunissement interne de l'ananas. Recherches des moyens de lutte. Fruits, 34, 399-415.

[13] Reinhardt, D.H.R.C.a.N., L.P.A. (1986) NPK et sources de potassium dans l'ananas "Perola" dans la micro-région à Bahia de Feira de Santana. In: Congrès international de fruits, Actes, Brésil, 41-46.

[14] Spironello, A., Quaggio, J.A., Teixeira, L.A.J., Furlani, P.R. and Sigrist, J.M.M. (2004) Pineapple Yield and Fruit Quality Affected by NPK Fertilization in a Tropical Soil. Revista Brasileira de Fruticultura, Jaboticabal SP, 26, 155-159. https://doi.org/10.1590/S0100-29452004000100041

[15] Djalalou-Dine, A.A.A. (2013) Governance, Marketing and Innovations in Beninese Pineapple Supply Chains. A Survey of Smallholder Farmers in South Benin. Wageningen University, Wageningen.

[16] Agbangba, C.E. (2008) Contribution à la formulation d'engrais spécifique pour la culture de l'ananas par le diagnostic foliaire dans la commune d'Allada. Université de Parakou, Parakou. 
[17] Sossa, E.L., Amadji, G.L., Vissoh, P.V., Hounsou, B.M., Agbossou, K.E. and Hounhouigan, D.J. (2014) Caractérisation des systèmes de culture d'ananas (Ananas comosus (L.) Merrill) sur le plateau d'Allada au Sud-Bénin. International Journal of Chemical and Biological Science, 8, 1030-1038. https://doi.org/10.4314/ijbcs.v8i3.17

[18] Dagnelie, P. (2003) Principes d'expérimentation: Planification des expériences et analyses de leurs résultats. Les presses agronomiques de Gembloux, 388.

[19] Watts, B.M., Ylimaki, G.L., Jeffery, L.E. and Elias, L.G. (1991) Méthodes de base pour l'évaluation sensorielle des aliments.

[20] Morineau, A. (1984) Note sur la Caractérisation Statistique d'une Classe et les Valeurs-tests. Bulletin Technique du Centre de Statistique et d Informatique Appliquées, 2, 20-27.

[21] Husson, F., Lê, S. and Pagês, G. (2010) Exploratory Multivariate Analysis by Exemple Using R. Taylor and Françis Group, Abingdon-on-Thames.

[22] Py, C., Lacoeuilhe, J.J. and Teisson, C. (1987) L'Ananas, sa culture, ses produits. Maisonneuve G.P. \& Larose, Paris.

[23] Soler, A. (1992) L’ananas: Critères de qualité. Montpellier.

[24] Scohier, P. and Texido, R. (2001) Ananas. In: Raemaekers, H.R., Ed., Agriculture en Afrique Tropical, Direction Générale de la Coopération Internationale (DGCI), Rue des Petits Carmes Bruxelles, Belgique, 302.

[25] Paull, R.E. (1993) Pineapple and Papaya. In: Seymour, G., Taylor, J. and Tucker, G., Eds., Biochemistry of Fruit Ripening, Chapman \& Hall, London.

https://doi.org/10.1007/978-94-011-1584-1_10

[26] Saradhuldhat, P. and Paull, R.E. (2007) Pineapple Organic Acid Metabolism and Accumulation during Fruit Development. Scientia Horticulturae, 112, 297-303. https://doi.org/10.1016/j.scienta.2006.12.031

[27] Veloso, C.A.C., Oeiras, A.H.L., Carvalho, E.J.M. and Souza, F.R.S. (2001) Resposta do abacaxizeiro à adição de nitrogênio, potássio e calcário em latossolo amarelo do nordeste paraense. Revista Brasileira de Fruticultura, Jaboticabal, 23, 396-402. https://doi.org/10.1590/S0100-29452001000200040 